\title{
LA HABANA, UN PAISAJE URBANO
}

\author{
POR \\ FRANCISCO TOVAR \\ Universidad de Lérida
}

\begin{abstract}
Cuando John K. Wright acuerda con Sir Douglas Newbold, citándolo, que el conocimiento geográfico ha de transmitirse ofreciendo del espacio "la visión, ese estado de la mente y del corazón que no se limita a digerir evidencias sino que transforma la evidencia en juicio, en cuadro viviente de una comarca" (Wright, 171), está admitiendo que ambos, en su discurrir científico, cuentan tantocon la presencia de un mundoreal como con sus múltiples representaciones. En cualquier caso, el paisaje no es patrimonio exclusivo de una ciencia ni coto vedado de unos oficiantes iniciados; forma parte de un proceso vivo que incluye al sujeto en la medida en que habita una cierta tierra incógnita. Como afirma David Lowenthal, los reflejos del mundo, con las ideas que esconden y revelan, son el resultado de una realidad concreta, extraña a los textos, y del deseo del individuo por poseer y proyectar aquello que más le afecta e interesa, fijándolo en una nueva fórmula efectiva, coherente y adecuada. El sujeto solo es el único responsable común de una geografía que ordena sus figuras en los límites de un espacio propio, modelado por:
\end{abstract}

refracciones a través de las lentes personales de la cultura y fantasía ... Todos somos artistas y arquitectos paisajistas, creamos orden y organizamos el espacio y hasta la causalidad de acuerdo a nuestras percepciones y predilecciones ... Como Raleigh escribi6: "No es la verdad, sino la opinion, la que viaja por el mundo sin pasaporten (Lowenthal, 216 ).

Desde sus mismos inicios, la literatura sabe de comprensiones y entiende de complementariedades, tratando de materializar sus visiones en las páginas de sus documentos ficticios. La configuración literaria, en su arriesgado juego expositivo libre y cuidadosamente medido, también se ocupa en registrar las imágenes de una geografía física, sitiándola con palabras. Sin olvidar los principios heredados de bondad, veracidad y belleza, ha de aceptar su condición mestiza y la complicación de sus relaciones, incluyéndolo todo en los límites de su propia historia convenientemente actualizada. El resultado nunca será perfecto ni definitivo, pero sí mostrará la experiencia y el testimonio de un 
escritor que pretende construir, con sus signos, un discurso consciente, intencionado y razonable, hecho a la medida del pequeño mundo del hombre.

\section{VISIONES DE LA HABANA}

La ciudad de La Habana ha interesado a propios y viajeros por sus mismas características geográficas; por su presencia y desarrollo histórico; y por la sugerencia de sus paisajes urbanos. Sea como fuere, todos coinciden en señalar ese lugar concreto, al borde del mar y levantado sobre la piedra, como el dintel entre dos mundos; sitio de paso, de largas estancias o de nacimiento, en el que se cumple la celebración de un ritual impresionante y sorprendente que se vuelve a mostrar, en forma diferente, la ajustada arbitrariedad de la naturaleza, la lógica de sus leyes y la coherencia de sus reglas. El trazado y la orientación de sus calles; la situación de sus plazas; la pluralidad de sus órdenes arquitectónicos, superpuestos y sucesivos; la abundancia de sus columnas y rejas; la luz que reciben y tamizan las fachadas de los edificios y el interior de las casas, mezclada con las sombras de los rincones particulares y públicos; la rigurosa exuberancia de su vegetación interior y exterior, propia de un clima húmedo y caluroso, capaz de demostrar su fuerza constructiva y su tremenda capacidad de destrucción; la certeza y el misterio de todo lo anterior, íntimamente ligado a su evidencia física y a la de sus relatos, convierte el paisaje habanero y a las figuras que lo habitan en símbolos reales, a la vez crueles y amables; comunes e íntimos; siempre sugerentes, que merecen ser atendidos, entendidos y descritos.

En La Habana que descubre Humboldt, el europeo se sentirá admirado, olvidando los peligros de las grandes ciudades antillanas, pero, como también el mismo Humboldt escribe, dejándose copiar por Carpentier, deberá aceptar la invitación que la ciudad le hace y comprender los elementos de un vasto paisaje, después de "contemplar esas fortalezas que coronan las rocas al este del puerto, ese lago interior, rodeado de poblados y haciendas, esas palmeras que se elevan a una prodigiosa al tura; esa ciudad medio oculta por una selva de mástiles y los velámenes de las naves" (Carpentier, La ciudad 9-10). La visión de La Habana que nos transmite Humboldt, con la intención de encajar el nuevo espacio que trata de describir en un orden referencial diferente, culturalmente condicionado por las imágenes de su mundo, no excluye otros registros europeos, que, lejos de negar el valor de la realidad heredada, con su esteticismo, recoge el que ha encontrado en su viaje, con el suyo, enriqueciendo el resultado.

La Habana también fascina a otros testigos extraños, ocupando las páginas de sus libros y el espacio de sus crónicas. Por citar sólo uno de esos testimonios más próximos, Manuel Vicent señala el atractivo de la ciudad porque al contemplar sus ruinas siente el íntimo resplandor ya visto en los cuadros de Piero della Francesca. En los trozos de las fachadas de la ciudad se esconden amarillos "arañados, verdes de manzana podrida, azules desvaídos, rosas con tonalidades de siena o malvas sucios" (Vicent, 56). Esos colores renacentistas, 
que en su nueva presencia material han añadido a la calidad descrita de una pintura plana la materialidad de los volúmenes, pretende sugerir a un lector atento y distante una necesaria visita. Alli, la persona podrá comprobar que unos restos viejos son aún capaces de recoger los rayos del sol para proyectarlos en un verdadero sueño dorado.

Reinaldo Arenas, como cubano, recuperará su ciudad contándola con el miedo de una pasada experiencia particular y sintiéndola como una trampa presente, enmascarada tras un exigido encuentro emotivo y nostálgico. El escritor volverá del revés su exilio amable y tranquilo para notar de nuevo en su rostro, aunque sólo sea por un momento, la brisa de su tierra, pero también para enfrentarse a sus fantasmas y espantarlos de una vez por todas. Con uno de sus personajes literarios, Reinaldo Arenas, nada más llegar a La Habana, querrá pasear por sus calles, aquéllas que había transitado de joven y en las que había aprendido a ser él mismo. Ismael-Reinaldo no sólo pretenderá visitar su barrio sino pararse en aquellas esquinas conocidas, tocar sus paredes y hasta apoyarse en los postes de electricidad, llegando a fijarse uno concreto, ése en el que "a veces se recostaba para esperar el ómnibus" (Arenas, 137). También desea ver los portales de las casas; sentir en sus pulmones el aire de la tarde y en su piel las sombras singulares de esas noches del trópico que guarda en su memoria. Quiere el sujeto, en el reflejo ambiguo de su retorno, comprobar que, a pesar de todo lo que ha sufrido en ese paisaje éste no le es hostil; que, por el contrario, aún puede ser acogido como antes, con "una dulce y sensual sensación de complicidad donde todas las fronteras quedan eliminadas" (137). Necesita volver para escuchar otra vez su idioma, "ese ritmo intransferible, ese balanceo, no del español sino del cubano, y no del cubano sino del lenguaje que se habla exactamente en el pueblo" (137); para confundirse con sus semejantes y entretenerse mirando sus movimientos; para diluirse con los suyos y no acabar muriendo en la obligada soledad de su exilio,o definitivamente anclado en una marginación. Reinaldo Arenas repite, escribiéndola, la aventura íntima de un nuevo viaje mítico que, en su particular discurrir, confirma la naturaleza de su héroe y le ayuda a comprender que, para reforzar sus odios y “disfrutar aún más de su soledad, se imponia un regreso al paisaje amado (donde tanto lo habían jodido) para luego abandonarlo definitivamente" (137).

El sujeto quizás se engaña en sus propósitos, pero no se equivoca al representar sus imágenes. Las del pretérito todavía guardan un registro común con la realidad presente, y ésta, sin embargo, ya no es la misma. Siempre queda algo de aquel espacio que fue y todavía sigue admirando y sorprendiendo al paseante propio, cuando se atreve a jugar con sus recuerdos, ofreciéndolos ahora como testimonio vivo de un deseo tramposo, que también se atreve a explicar el escritor. La Habana que cuenta el Ismael de Reinaldo sigue siendo clara y tibia; mágica en el tiempo detenido del discurso; exclusiva para el individuo que la nota dentro, pero también enseña la verdad de su actual miseria. En su registro literario, La Habana de Reinaldo Arenas destaca por su luminosidad, sus olores, su tacto, sus sonidos, sus saludos, su invitación cómplice. Cercado por sus 
recuerdos y aferrado a su ensoñación, la máscara del escritor se moverá en el interior de un paisaje urbano en el que, despierto, sabrá descubrir, en su historia, otra ciudad capaz de deprimirlo. En esta última caben restos de:

casas apuntaladas, paredes derruidas, edificios reducidos a escombros, latas y cartones que tapaban un hueco, charcos de agua putrefacta, enormes macetones de basura acumulada en las puertas de los edificios, y sobre todo aquella polvareda y aquella impresión de deterioro general, pues no se trataba de viejos edificios, o de balcones apuntalados o de paredes remudadas, se trataba de moho, de algo que carcomía y subía royendo, contaminando no sólo las paredes, sino los troncos de los escasos árboles, las hojas, el aire y hasta los rostros de las personas (140).

Mientras La Habana Vieja se conserva aislada para enseñarla a los turistas de paso, y como ghetto idílico para aquellos que vivieron la ciudad desde niños, maravillándose tantas veces "ante aquellos balcones bordados de hierro, columnas y vitrales" (155-156); la de extramuros muestra sus miserias. Sea como fuere, la estampa habanera de Reinaldo Arenas, con sus mezclas y contrastes, fija el complicado proceso de una historia problemática y mestiza en la que el sujeto trata de sobrevivir libremente con la realidad de su espacio y en la medida en que se lo permite la muestra de sus símbolos. Las figuras del narrador le obligan a preguntarse:

¿Cómo aceptar que aquella juventud, lo único realmente hermoso de su vida, se haya perdido? ¿Y cómo aceptar que aquel lugar donde había pasado esa juventud sea ahora s6́lo una prisión? Dios mío, ¿y ó́mo aceptar, cómo concebir que por simple sentimentalismo, por mera cobardia, por pura nostalgia, haya yo regresado a esta prisión? Y saber que estoy aqui de paso, y que debo alegrarme que asi sea, que este sitio que es mi tierra, que este paisaje que es $\mathrm{mi}$ mundo, el único mundo que reconozco como mio, sea precisamente el lugar donde no pueda vivir y dónde sólo pueda venir de visita y como extranjero (145146).

Cabrera Infante incluye La Habana en sus páginas de ficción biográfica, envolviendo el conjunto en una atmósfera de posesivo aroma dulzón, en donde encaja las figuras y los lugares del adulto que narra una experiencia iniciática adolescente. El paisaje ciudadano va ligado a la aventura de un héroe protagónico que se empeña en descubrir los trabajos del sexo. El barrio, las calles, las casas, las estancias y las gentes - reducidas éstas casi exclusivamente a la sucesiva presencia individualizada de las hembras, localizadas en su correspondiente coto por un curioso cazador furtivo, que a su vez se quiere ver cazado-, se dan cita en un sólo libro que, en definitiva, exhibe el sensualismo obsesivo de un particular infante difunto. El resultado final, con su artificio, es efectivo porque puede ser contemplado por cualquier voyeur de sala cinematográfica, reconociendo en los pases de la pantalla el gozo de sus pequeños vicios. 
La Habana de Cabrera Infante es una caja cerrada en la que guarda sus fetiches, pero también es la ventana iluminada y abierta en la que se proyecta la representación de esos mismos fetiches, exponiéndolos mediante un diálogo solitario y parentético. El escritor se mueve con todo el descaro de un testigo oculto que no teme señalar sus gestos, amparándose en la oscuridad de la sala y en la cierta verdad de sus sueños. En ese discurrir próximo y distanciado, La Habana se mira desde el Malecón y se espía desde las calles antiguas. El primer encuadre maravilla por el artificio luminoso de los anuncios de neón, más espléndidos en el Parque Central, en donde destaca el de una bañistaintermitente enfundada en su maillot de marca, que en el parque Maceo. Arropada en esas luces, la noche habanera se convierte en "un sortilegio único, inolvidable" (Cabrera 21): sus vías principales se presentan con su falso día gratis. Dos mundos caben en una sola visión: el que se contempla y aquel en el que se encuentra el espectador. En cualquier caso, uno y otro, confundidos, ponen de manifiesto que la:

fosforescencia de La Habana no era una luz ajena que venía del sol o reflejada como la luna: era una luz propia que surgia de la ciudad, creada por ella, para bañarse y purificarse de la oscuridad que quedaba al otro lado del muro (21).

La visualización de ambos espacios, en su conjunto y en cada una de sus partes, obligan a imaginar el infinito, creyéndolo ilusoriamente eterno dentro de sus propios límites. Quizás haya que creer también que ese mismo infinito tiene su eternidad en el recuerdo.

En Zulueta, una de las calles de la ciudad vieja donde se abre el portal de la Manzana de Gómez, el personaje de Cabrera descubrirá el sueño de una arquitectura interminable en la que destaca no el artificio natural de las luces de un nocturno habanero, sino la naturaleza cercada de un horizonte urbano repleto de columnas, que otra vez, como antes, revela la idea de infinitud. Sea como fuere, La Habana de Cabrera Infante se ordena en el correr de unos fotogramas literarios en los que se van identificando las visiones de un verdadero mirón miope.

Lezama Lima sitúa a sus personajes novelescos en la tramoya real de sus sitios. Las mansiones, las calles y las gentes de La Habana, forman parte de la obra de este otro escritor cubano, que escoge el paisaje habanero para mostrarlo cuidadosamente y descubrir con él la realidad mestiza de sus signos. La geografía de la ciudad representada por Lezama tiende a materializar los conceptos, transmitiendo una experiencia y una conciencia personal que sorprende y fascina con su sensibilidad y su inteligente ingenio. Los misterios de un espacio concreto se alimentan en los principios mágicos de una estética barroca plenamente entendida y delicadamente construida. Los huecos de las fachadas hablan al transeúnte, convirtiéndolo en cómplice del sentido que tienen todos -aberturas, palabras y personas-, en su misma distribución externa, caóticamente equilibrada, y en lo que comprenden en su interior. Por 
ellos entra la luz, el aire y las voces de fuera, pero también por ellos salen los susurros de salas y salones; el sonido de los pasos en corredores y escalinatas.

La planta tremenda de una casa singular surge de las sombras nocturnas en cualquier esquinailuminada por la oblicuidad lunar, invitandoal transeúnte curioso a establecer sus necesarias relaciones. Edificio y persona se identifican en la medida en que ambos forman parte de un mundo que se levanta a ras de suelo, y coloca a sus individuos por encima del nivel habitual del paseo. Uno y otra comprenden todo su encantamiento en la fantasía de su abigarrada arquitectura natural, ligada a su propio orden lógico. La segunda acuerda con la primera en la solidez de sus columnas; en la pesadilla iconográfica de sus adornos y en la realidad de su imposible sueño, señalando las dos el espacio de un conocimiento vivo, sensible e inteligente en el que cabe la herencia de la cultura colonial y el legado de la propia tierra. La técnica, en su descubrimiento y en su utilización decadente, no permanece ajena a este proceso. No resulta gratuito que Lezama describa una de las mansiones que se le revelan en cualquiera de sus paseos por La Habana, bajo la luz de la luna, destacando en ella su impresionante columnata y los motivos de las figuras que se aferran a su superficie, poniendo en contacto el extremo de sus bases y el de sus capiteles (Lezama, 486); tampoco extraña que el escritor señale, deteniéndose en los detalles mínimos, el acceso y la distribución interior de sus casas, con su sugerente orden intimo (170-171).

Las calles también cuentan en el espacio habanero de la obra de Lezama Lima. En ellas el paseante reflexiona sobre el urbanismo de la ciudad y la posibilidad que le ofrece el trazado callejero de elegir el trayecto más adecuado, siempre acorde con los humores y fastidios del sujeto. Si éste, viniendo del Espigón hacia el Parque Central, quiere entretenerse en el camino para conversar con alguien conocido, para mirar las vidrieras de los comercios, para oír el anuncio de los números de la suerte o para ver la edición de los libros más recientes, pasa por Obispo. Si por el contrario pretende ir más de prisa y no quiere que le interrumpan en su viaje, sube por Obrapía. Sea como fuere, el escritor no deja de maravillarse de que:

dos calles, en un paralelismo tan cercano, pudieran ofrecer dos estilos, dos ansiedades, dos maneras de llegar, tan distintas e igualmente paralelas, sin poder ni querer juntarse jamás (372).

Lezama tampoco deja de observar y contar el comportamiento de las gentes que viven y se mueven dentro de los límites habaneros, de acuerdo con sus medidas, con los horarios y con las costumbres de su ciudad $(222,429)$.

El plano de La Habana que expone el escritor, con sus lugares, sus itinerarios y sus figuras, viene a configurar todo un universo que se mece en función de estímulos físicos e intelectuales; que mezcla los planos de un solo ser imaginativo ligado a los ritmos de los hábitos propios y de las costumbres públicas que contempla, atado a la valoración de una estética barroca y a la 
cuidadosa exposición simple de sus impresiones. El resultado de esa conciencia paisajística se traduce en la representación de una ciudad que se mantiene siempre fiel a los dictados de la mente y del corazón; que ha transformado la evidencia en juicio; que se transmite con el cuadro viviente de un espacio limitado y concreto.

Alejo Carpentier admite haber cobrado conciencia de su ciudad en 1912. Tenía entonces siete años, "esa edad en que empieza uno a ver las cosas con un pequeño espíritu analítico incipiente, en que uno recibe impresiones del exterior y esas impresiones empiezan a fijarse en la mente y a crear un panorama del mundo en que vive, y que empieza a descifrar, a ver, a interpretar y a acomodarse en cierto modo con los elementos circundantes de la vida" (Carpentier, "Sobre La Habana" 60-61). Para ese niño, el lugar formará parte de un paisaje en continuo movimiento; de un estar sensible y atento, tremendamente complicado, donde se sitia la impresión de la historia y se localizan las imágenes de un testigo inocentemente despierto, capaz aún de contemplar la maravilla y la sorpresa de una ciudad verdaderamente barroca en sus orígenes y en su posterior desarrollo. En la realidad de un sólo espacio se pone de manifiesto la certeza de una geografia física particularmente objetiva. En ella caben tanto los registros de la propia herencia, con su mezcla, como los que se han añadido en un proceso histórico naturalmente mestizo y sucesivo. El resultado de esta conciencia acumulativa, convenientemente relacionada en su necesario aislamiento, es el que se expone en los diferentes textos de Alejo Carpentier y en la imaginería de su singular visión del paisaje habanero. Todos se encuentran dentro de los límites de la experiencia y pretenden cercar, fijándolos y transmitiéndolos, los diferentes reflejos del conocimiento y los trabajos que ha de realizar el hombre para alcanzarlos y ofrecerlos.

Alejo Carpentier es un sujeto que hunde sus raíces en La Habana, pero sabrá admitir también que únicamente llega a entender su ciudad sintiéndola y contándola como viajero. Esa doble perspectiva permite al escritor jugar con sus figuras y encajarlas en la coherencia de un sólo discurrir múltiple. La sensibilidad, la información, la inteligencia y los recursos de Carpentier caben en la maravillosa realidad barroca de su quehacer literario. Alejo se coloca frente a su espacio y en él sitúa al lector como ese necesario compañero que, tras una larga ausencia, es capaz de aproximarse más a sus imposibles imágenes, viéndolas, organizándolas y proyectándolas en un ajustado concierto, cuidadosamente construido y repleto de registros. Siempre cabe en la pieza la actitud y la labor de un individuo responsable y comprometido.

Este otro cubano, ligado a su tierra, podrá contemplar el paisaje habanero que sirvió de marco a su niñez y adolescencia y que, más tarde, utilizará el adulto, con "ojos nuevos y espíritu virgen de prejuicios. Además, las andanzas por otras tierras suelen traer a la mente más de un punto de comprensión y referencia ... Y, hostigado por una curiosidad nueva, el observador en casa propia se siente impelido a revisar valores, a rejuvenecer sus nociones, a visitar el barrio que antaño se le antojaba desprovisto de interés, a explorar la calle que 
no recorrió nunca ... Comprende entonces que el hábito, la costumbre, la obligada convivencia de hombres y piedras, son terribles neutralizadores de emociones, y que en el fondo encierra una gran verdad la boutade de Cocteau: 'Si se exhibieran centauros en el zoológico, nadie iria a verlos" (Carpentier, "La Habana vista" 181). Unicamente como turista despierto, instruido e inteligente, alejado de excesivas nostalgias, aliviado del peso de las anécdotas no significativas y liberado de una exclusiva sobrecarga literaria, Carpentier podrá dar cita a sus sitios en la medida de sus historias.

En un largo fragmento descriptivo de Los pasos perdidos, el narrador, sin llegar a nombrarla, señala La Habana como un lugar que merece ser expuesto en un discurso que mezcle la sorna y el cariño, pero también como una capital que, instalada al borde del mar y extendida a lo largo de una costa de arena, custodiada por las rocas que sirven de base a diversas construcciones fortificadas, se presenta de repente ante un espectador curioso e interesado, enfrentándolo a la realidad de una ciudad condicionada al rigor de una próxima geografía física; habitada por unas gentes marcadas por una climatología exigente; y sometida a un proceso histórico, propio y extraño, siempre dependiente y, sin embargo, adaptado a la singularidad común de una naturaleza mestiza. El espacio habanero posee sus playas y sus cerros; sufre epidemias y plagas; se va edificando en la medida en que lo exige su organismo, en el que cabe comprender tanto la semilla primera, con su misterioso y lógico desarrollo relacionado, como el resultado de una constante acumulación, consecuentemente asimilada en sus leyes íntimas y en sus fórmulas superficiales, con la evidente relación de sus misterios. En cualquier caso, todo se superpone, sin confundirse, en un lugar concreto que tiene algo de "aerolito salido de una mano celestial"; de universo ordenado, tremendamente caótico; de rutina cotidiana y de esfuerzo por superarla y vencerla; de origen, de fin y de proyecto. Ahí se lleva a cabo la mejor siembra, y encuentra su mejor caldo de cultivo, el duende maligno del polen que lleva el aire, figurilla que carcome, con su invisible moho volante, los espacios donde asienta sus raíces. La fantasía real del lugar, sustentada sobre la superstición popular, con sus ritos, y la religiosidad asimilada, con los suyos, a las que se añaden otros registros informativos, actúa en los relatos como un verdadero personaje capaz de "abrir lo cerrado y cerrar lo abierto, embrollar los cálculos, trastocar el peso de los objetos, malear lo garantizado" (Carpentier Los pasos, 41). Alli se manifiesta el secreto del gusano que nadie ha visto nunca pero está en la vida y en la conciencia de las gentes, porque en verdad existe, "entregado a sus artes de confusión, surgiendo donde menos se le espera, para desconcertar la más probada experiencia" (42). Ahí se encuentra la historia de la tierra y la que llegó de fuera, fijando sus procesos, elaborando sus dictados y nombrando a sus vigilantes. La Habana, en la realidad de su conjunto es, para Alejo Carpentier, y así la enseña, el inicio y el final de un viaje mítico, además de ser el centro de un ciclón que inicia su danza circular en algún lugar del Océano (43).

En ${ }_{i}$ Ecue-Yamba-O! ya Alejo Carpentier apunta la rápida impresión que de La Habana recoge un personaje cubano, doblemente marginado por su condición 
de negro y de reo. El escritor señala un trozo de la ciudad, próximo a la estación de ferrocarril, como parte significativa de un universo similar, más amplio, en el que también se reproduce la mezcla contemplada en lo mínimo. El gentío; los vehículos parados y los que circulan por las calles; los cafés, los comercios y los servicios públicos; la exhibición de los múltiples anuncios; la borrachera de colores; la calidad de una atmósfera velada y brillante, descubren al sorprendido espectador transeúnte un cierto mundo maravilloso (Carpentier, ${ }_{i}$ Ecue-YambaO!, 101). En "Viaje a la Semilla", el narrador cuenta cómo los restos de una demolición, que ha de convertir una lujosa mansión habanera en ruinas y solar, aún son capaces de extraer de la memoria de un testigo vivo los recuerdos de su propia historia común (Carpentier, Guerra del tiempo, 55-81).

Más tarde, en El siglo de las luces, el cubano insiste en incluir de paso, dentro de un discurso más extenso, su visión de La Habana (11-16). Algo más breve es la presencia de La Habana en El recurso del método, donde se incluye la figura del dictador viajero. El paisaje habanero también ocupará su sitio en Concierto barroco (17-18), formando parte de una pieza completa en la que la ciudad marca uno de sus tiempos lentos, dando pie al indiano para detenerse en su camino, acomodar de nuevo su equipaje, sustituir a su compañero muerto por otro más adecuado, y emprender otra vez la marcha, tratando de encontrar, al otro lado del dintel, el origen de esa herencia europea que justifique su ser americano. El sujeto volverá a su tierra de nacimiento, después de haber aprendido la lección de su aventura y cumplido el rito de un viaje mítico distinto y repetido. En La consagración de la primavera, La Habana encaja en el relato en la medida en que una y otro, en su concreta manifestación, forman parte de un complejo simbólico vivo que, en sus ajustados límites, sirve de lugar de referencia, resumiendo y proyectando, en un único espectáculo, las figuras enmascaradas de un sólo personaje íntimo, compartido y multiplicado.

El paisaje ciudadano de Alejo Carpentier es, en definitiva, algo más que una estampa evocadora, repleta de anécdotas dispersas; resulta un lugar necesario para sentir, comprender y ordenar el discurrir del hombre de su tiempo, dentro de su misma historia. En cualquier caso, la nostalgia del espacio y el peso excesivo de los recuerdos no caben en el quehacer narrativo de Alejo Carpentier ni en los sitios en los que se representa. La Habana juega en la obra de este cubano un papel más importante: da fe de la realidad de un mundo fantástico que, exhibido con todas las técnicas del barroco, y todos los recursos comprometidos del escritor atento y responsable, exponela complicada naturaleza de quien desea encontrar en el mapa un lugar en el que darse sentido.

\section{UN DETENIDO PASEO POR LA CIUDAD DE LA HABANA}

En La ciudad de las columnas, Carpentier muestra el paisaje habanero, acordando sus palabras con las imágenes dispersas, recogidas en en el resto de su obra anterior y las que le ofrecen unas fotografías que, a su vez, reproducen fragmentariamente los detalles reales de una geografia urbana misteriosa. El 
resultado de esta mezcla se traduce en un discurso que se mueve al ritmo de un paseante ocioso, empeñado en desvelar a sus cómplices el valor de sus signos. El narrador no es el guía que señala, ni el vecino del barrio; es el hombre entero, y éste sólo refiere algunos destellos contemplados a través del objetivo de una cámara convenientemente personificada. Con ella se enfoca:

la vieja ciudad, antaño llamada de intramuros, ciudad en sombra, hecha para la explotación de las sombras, sombra, ella misma, cuando se la piensa en contraste con todo lo que fue germinando, creciendo hacia el oeste, desde los comienzos de este siglo, en que la superposición de estilos, la innovación de estilos, buenos y malos, más malos que buenos, fueron creando en La Habana ese estilo sin estilo que a la larga, por proceso de simbiosis, se amalgama, se erige en un barroquismo peculiar que hace las veces de estilo, inscribiéndose en la historia de los comportamientos urbanísticos. Porque, poco a poco, de lo abigarrado, de lo entremezclado, de lo encajado entre realidades distintas, han ido surgiendo las constantes de un empaque general que distingue a La Habana de otras ciudades del continente (Carpentier, La ciudad, 13-14).

La singularidad se instala en la pluralidad y todo se presenta en una linealidad compuesta por puntos e impresiones sucesivos que tienden a reproducir la extraña maravilla de un mundo entrañable y retorcido. El tiempo, las personas, las cosasy los hechos, se encuentran con su historia en la representación de sus figuras, reconociéndose todos en cada esquina de una ciudad que se perfila en una construcción repleta de adornos. El escritor ejerce de cronista en una dinámica particular donde cada imagen se asume como propia, con todas las ciertas ambigüedades y contradicciones que ello implica. El testimonio de Carpentier, cuidadosamente intencionado, no deja de ser un documento útil y, sin embargo, voluntariamente gratuito, capaz en sí mismo de exponer un espacio, tremendamente vivo, adaptado al juicio del hombre y al misterio de unas leyes lógicas que rigen un medio natural y fantástico. La Habana se convierte en un reflejo de realidades que se ofrecen en su excesiva imaginería y asaltan con las formas de un estar que se fórmula en un decir coherente, repleto de contenidos y sometido al artificio de sus representaciones.

Para Carpentier, las columnas son los puntales de La Habana; el origen de un círculo y el sostén de un edificio que, sin carecer de antecedentes en el alarife español, apunta la gracia de esos "patios humbrosos, guarnecidos de vegetación, donde troncos de palmeras ... convivieron con el fuste dórico" (21). En sus inicios, estos soportes verticales se localizaban únicamente dentro de las casas sólidamente construidas, aunque simples en su aspecto exterior; aguantaban el peso de refinados arcos interiores; o mantenían el de sus hermanos callejeros. No es de extrañar que así fuera en "una ciudad cuyas calles eran tenidas en voluntaria angostura, propiciadora de sombras, donde ni los crepúsculos ni los amaneceres enceguecian a los transeuntes, arrojándoles demasiado sol en la cara" $(21,26)$. En los viejos palacios de La Habana, y en algunas de sus antiguas mansiones señoriales, algo más modestas, que aún conservan la estructura 
original, las columnas son un lujo y un adorno íntimo. Sólo más tarde, a finales del XVIII, saldrán a la calle y, en público, crearán “-aún en días de decadencia arquitectónica evidente- una de las más sólidas constantes del estilo habanero" (26), ése que está lleno de nervios de piedra y obra y da a la ciudad una imagen propia que corre paralela al catálogo de una historia columnaria, identificada con sus diferentes edades.

Alejo Carpentier mira, recuerda y escribe que, en La Habana, puede "un transeúnte salir del ámbito de las fortalezas del puerto y andar hasta las afueras de la ciudad, atravesando todoel centro de la población, recorriendo las antiguas calzadas del Monte de la Reina, tramontandolas calzadas de El Cerro o de Jesús del Monte, siguiendo una misma y siempre renovada columnata, en la que todos los estilos de la columna aparecen representados, conjugados o mestizados hasta el infinito" (26-32). Entre esta selva artificial, construida por el hombre, destacan en La Habana otros elementos arquitectónicos imprescindibles, que, junto a las gentes que circulan pasando con su bullicio, son imprescindibles para entender la complejidad del conjunto habanero. Este exhibe la exuberancia de un paisaje sincrético que, en su habitual simbiosis abigarrada, posee toda la fuerza de un tremendo horror al vacío.

La reja también tiene su sentido en los límites de su historia. Ligadas las dos a las casas y a quienes las habitan, y dentro de una geografía antillana, cuyo catálogo de mansiones y de hierros se multiplica tanto como su registro columnero, no deja de sorprender y admirar la presencia de esas forjas bajas, más viejas -y aquí cabe contemplar también la existencia del guardacantón-, o la que asalta y atrae desde arriba, ya a partir de este siglo, suspendida en balcones y galerías, con sus guardavecinos. La orfebrería ferruginosa, con sus variantes artesanales especificas, se adosa a los huecos abiertos de las fachadas, separando los mundos que ya se han dividido con la construcción de los muros. El enrejado configura un adorno, de existencia casi atemporal y a la vez exactamente cronológica. El proceso histórico ya contemplado y perseguido en las columnas se repite en coherente diálogo con su entorno y con las personas que lo viven.

En las esquinas, el guardacantón preserva los ángulos de las fachadas y custodia la entrada de las puertas mayores, señalando, en sus quicios, la verdad de un mundo peculiar que coincide con la época de los coches de tiro con yantas de metal. En esas bajas corazas, se dibujan inesperados panoramas "poblados de signos solares, de toscos motivos ornamentales que pueden tomarse por figuraciones de estrellas" (54) o por fantásticos petroglifos, que adquirirán relevancia al asumir, fuera, la personalidad que le llega del interior de la mansión que los adosa.

Las primeras rejas bajas, más próximas a la tierra, son blancas, enrevesadas, casi vegetales. En ellas se expone una enredada abundancia que se materializa en complicadas cintas metálicas. Mirándolas, se notan reproducciones de liras; de motivos florales, reunidos o aislados; de vasijas evocadoramente romanas; de volutas innumerables que, por lo general, acogen, enmarcándolo, el nombre de 
una mujer, que se supone sea el de la antigua dueña de la casa, o la cifra de una fecha histórica que, con frecuencia, en la zona de El Vedado, sitúa al paseante en alguno de los años setenta, los que corresponden a la primera década del último tercio del siglo pasado. Esporádico es el encuentro de herrajes que se remonten a los tiempos de la Revolución Francesa. La reja residencial inferior también cuenta con rosetones "de colores de pavo real, de arabescos entremezclados" (43). Carpentier destaca en La Habana las prodigiosas filigranas férreas de las carnicerías situadas en la Calzada de El Cerro, paisaje de hierros de lujo que muestran al paseante la grandilocuencia de sus formas en unos "metales trabados, entrecruzados, enredados en sí mismos, en busca de un frescor que, durante siglos, hubo de solicitarle a las brisas y terrales" $(43,48)$. Más severos son los enrejados puestos en algunas casas de madera que, asentadas en manzanas antiguas, acompañan a la mansión o a la vivienda de obra más sencilla. La austeridad de estas rejas, colocadas sobre fachadas modestas o adosadas a edificios señoriales discretos, aún se atreven a enseñar su "gótica estampa, adornarse de floreos nunca vistos, o derivar hacia un estilo sorprendentemente sulpiciano" (48). En cualquier caso, el bajo enrejado cubano de La Habana tiende a copiar "el motivo caprino de las rejas de la Casa de El Greco, evocar la morada de Aranjuez, o alojarse en las ventanas que imitan las de algún castillo de La Loire ..., lo peculiar es que esa reja sabe enredarse en todos los peldaños de la escala arquitectónico-social (palacio, cuartería, residencia, solar, covacha) sin perder la gracia que le es propia, y que pueden manifestarse de un modo inesperado, en una sola voluta de forja que cierra el rastrillo de una puerta de pobrísima y despintada tabla" (48-49). No hay que olvidar que, junto a estas referencias más concretas, libremente colocadas en su natural estrategia, caben otras que apuntan hacia anacrónicos alcázares moriscos o nuevos castillos cristianos medievales, además de aquellas edificaciones de heredado modelo afrancesado, similares a las de Blois o Chambord.

Este herraje inferior, más o menos afiligranado, en ocasiones se acompaña de marmóreas figuras realistas, extraídas de cualquier zoológico. En los barandales, también se acumula un catálogo animal, extraído de la fantasía escenográfica wagneriana, con su profusión de cisnes, o reproducen esfinges de clara estética, entre prerrafaelista y "wildiana", ligada a Mucha y a la Exposición de 1900.

La herrería superior sigue esa misma desproporcionada proporción, ya expuesta en las medidas de sus semejantes inferiores. Afincada en el espacio áereo, destinado a los altos municipales y comunitarios, destacan las formas metálicas de los guardavecinos,

verdadera frontera decorativa, puesta en el límite de una casa, $o$, en todo caso, de un piso, repitiéndose, en él -multiplicándose, por tanto-, toda la temática decorativa que ya había nacido en las rejas puestas al nivel de las calles, aupándose, elevándose con ello el barroquismo de los elementos arquitectónicos acumulados por la ciudad criolla (52). 
Allí se encuentran otra vez liras, claves de sol, rosetones, salvando el arte de la forja de un seguro peligro de extinción, ya anunciado con los últimos portafaroles, de los que todavía se guardan en La Habana algunas muestras hermosas y ocurrentes. Estas últimas piezas "solían sacar el brazo propicio sobre el arco mayor de la puerta mayor" (52), sosteniendo las lámparas que alumbraban las entradas de las casas grandes, formando con el guardacantón un completo conjunto custodio de puertas externas.

Los bordados y relieves ferruginosos, con sus dibujos calados y sus atractivas superficies, marcan, hacia afuera, el estilo callejero de La Habana y de Cuba entera, dando los rostros de una cara diversa que se asoma al paisaje exterior o al interior, acorde éste con las figuras que puede contemplar el viandante que no ha sido invitado a entrar en la vivienda.

Dentro de la casa cubana, en su paralelo habanero, tampoco se rechazan las ventajas del alarife trazado en las vías. Si en éstas se llega a perseguir el mayor número de esquinas, consiguiendo a veces que una misma plaza recoja cinco calles o se abra en otras tantas direcciones, aquélla, en la intimidad de sus corredores, zonas de distribución y estancias, se empeñará en copiar la misma estructura. Ambas garantizan el paso del aire, conduciendo sus corrientes y localizando perfectamente los sitios más frescos de la ciudad y de sus construcciones, convenientemente desplazados en el discurrir de las estaciones del año.

Mientras la ordenada distribución externa es patrimonio común, su par interior forma parte del secreto familiar y va ligado a actos de protocolo y urbanidad, a veces susceptibles de ser transgredidos para beneficio de propios y extraños. En La Habana, las visitas no han de incomodarse si, tras su primera acogida en el salón principal, más caluroso, se les abre la oportunidad de desplazarse con el mobiliario de acomodo y una vez superada la rigidez inicial, a otro sitio de la casa climatológicamente más amable. En esa búsqueda del confort juega un papel importante la mampara.

En sus diferentes formas evolucionadas, y en su determinada situación dentro de la casa, la mampara guía la brisa con un gesto civilizado que refuerza y ayuda al que, más rígido, justifica la construcción del corredor. Con estas barreras de tramoya, el aire es llevado casi de la mano al lugar elegido de la vivienda. Pero la mampara no sólo se levanta para sitiar la temperatura y encontrarse con la brisa, sino que también ordena las zonas de penumbra y claridad, además de fijar un complejo sistema de relaciones en las que cabe entender la particular exhibición del cubano.

Superpuesta a la entrada real de la casa, que no se abre o cierra en La Habana salvo en casos extremos de muerte o necesidad de los moradores, y, puntualmente, cuando soplan los nortes invernales, se encuentran las primeras mamparas, unas verdaderas puertas adosadas, con sus goznes invertidos, que responden al nivel social de los propios. Sus materiales son la madera y el vidrio, distribuidos, respectivamente, en los niveles inferiores y superiores, organización que únicamente establece variables en edificios de oficinas. Hay mamparas 
clásicas, ligadas a las casas corrientes, de común simplicidad, que se rigen por su utilidad y no se plantean una función decorativa; otras, de una majestuosidad útil y aspecto macizo, en las que predomina la grandilocuencia de su ornamento, que se exponen en mansiones lujosas. Aquéllas poseen cristaleras que, por lo general, se dividen en dos piezas opacas, "a menudo adornadas con calcomanías, rematadas, en lo alto, por una moldura de madera de diseño un tanto ojival, cuyos dos cuerpos eran cerrados por una borla de madera semejante a una granada" (63). Sus dibujos decorativos descubren los gustos de los habitantes de la casa, que elegirán sus muestras entre motivos florales, paisajes mínimos o escenas "humorísticas de tipo callejero -requiebro a la mulata, el marinero de juerga, el asno empecinado-, cuando no conjugaban el tema geométrico" (66), todas ellas compradas por metros en algún comercio de loza suficientemente surtido. Las segundas, guardando las distancias de calidad y de valor artístico, también presentan motivos vegetales, si bien se aproximan a registros que evocan a Borromini. Unas y otras añaden a esta común diferencia otras no menos significativas: la de separar a los moradores de la vivienda de la proximidad de la calle, manteniéndolos aislados en el interior, sin que ello implique una absoluta discreción ni una mayor independencia. Las personas pueden seguir viéndose y sintiéndose, lo que origina:

en las casas de mucha prole y mucha parentela, el hábito de conversar a gritos, de un extremo a otro de la vivienda, para mejor información al vecino de menudos conflictos familiares. El problema de la "incomunicabilidad", tantas veces planteado por los novelistas recientes, no se planteaba en casa de mampara, vibrante de cristales que transmitían cualquier pregon hasta las intimas penumbras del patio de aracas y albahacas (66)".

En edificios singulares -colegios, tabernas, hogares señoriales o palacios públicos-, esta escenografía interior llega a ser incluso determinante, colocándose a "medio camino entre las vegetaciones del patioy aquella polícroma frontera entre lo que era de la penumbra y lo que era del sol, que era el medio punto, elemento fundamental del barroquismo cubano" (67-68). Configura entonces la vidriera un inmenso abanico abierto sobre las puertas interiores. Más vidrio en un lujo semejante en materiales y distinto en concepción e interpretación. Aqui es donde el cubano, el habanero, se entretiene hablando con el sol, después de haberse procurado unos espejuelos que filtran sus rayos y le permite mirarlos de frente. El medio punto sirve de interprete en un discurso que transcurre en planos de inteligibilidad recíproca o de intima complicidad. En esta superficie traslúcida e iridiscente se mezclan los colores, sin historiar sus figuras, esporádicamente representadas por flores o motivos heráldicos, se atraen y proyectan los reflejos en:

triángulos combinados, ojivas entrelazadas, despliegues de colores puros, manos de enormes cartas, definidas y barajadas en cien casas de La Habana, que explica, por su presencia a la vez añeja y activa, ciertas características de 
la pintura cubana contemporánea. La luz, en los cuadros que esas figuras representan, les viene de dentro. Es decir, de fuera. Del sol colocado detrás de la tela. Puesto atrás de caballete $(77,80)$.

El círculo de este detenido paseo con Carpentier por La Habana se cierra, en La ciudad de las columnas, en un ritornello columnario que, en su espacio geográfico y en el que ocupa las páginas del libro, se convierten en eje modulor que sostiene el paisaje habanero, y alrededor del cual se organiza la realidad soñada del paisaje ciudadano que el escritor trata de transmitir (82). Con él, La Habana adquiere la dimensión que le corresponde, dentro de los particulares registros del barroco americano y europeo, y en la medida en que se aparta de estos últimos al no recoger, salvo excepciones, su "atirabuzonamiento de pilastras salomónicas vestidas de enredaderas doradas, sombreadoras de sacras hornacinas" $(82,84)$.

\section{A MODO DE CODA}

Los narradores citados, con la realidad de sus historias ficticias y la de su paisaje, representado, no temen usurpar el papel que tradicionalmente se reserva al geógrafo, al historiador o al arquitecto urbanista. La curiosidad y la atención les lleva a transmitir las impresiones particulares de un espacio concreto repleto de registros sensuales y de aquellos que se derivan de la cultura y de la fantasía.

Un mundo nuevo conocido se levanta con los sentidos y la inteligencia del hombre responsable y atento, empeñándolo en llevar a cabo una aventura que, necesariamente, exige un rito y reclama compañeros de viaje. La existencia del sujeto limitado, y sus proyectos, merece ser sitiada para entender aquello que afecta al individuo y comprender, después de descifrarlas, las fórmulas que tratan de contarlo. El resultado siempre es sugestivo en su natural mestizaje. La Habana sólo es el ejemplo de un lugar geográfico que, en sí mismo, y por la complejidad de sus relaciones, merece la condición de símbolo. Ella es ese lugar que Baudelaire encaja en sus versos y Alejo Carpentier transcribe al final de $\mathrm{La}$ ciudad de las columnas: "Temple où de vivants piliers laissaient entendre de confuses paroles" (84).

\section{OBRAS CITADAS}

Arenas, Reinaldo, Viaje a La Habana. Madrid: Mondadori, 1990.

Cabrera Infante, Guillermo, La Habana para un infante difunto. Barcelona:

Seix Barral. Biblioteca Breve, 1979.

Carpentier, Alejo, Los pasos perdidos. Barcelona: Barral Editores. Libros de Enlace, 1971.

El siglo de las luces. Barcelona: Barral Editores. Libros de Bolsillo, 1972. Concierto barroco. México: Siglo XXI Editores, 1974. 
La consagración de la primavera. Madrid: Siglo XXI Editores, 1974.

Guerra del tiempo. Barcelona: Barral Editores. Libros de Bolsillo, 1975. El recurso del método. Madrid: Siglo XXI Editores, 1976.

La ciudad de las columnas. La Habana: Letras Cubanas, 1982.

"Sobre La Habana". Conferencias. La Habana: Letras Cubanas, 1987, 59-89.

"La Habana vista por un turista cubano". Conferencias. op. cit., 181-201.

Lezama Lima, José, Paradiso. México: Ediciones Era, 1973.

Lowenthal, David, "Geografia, experiencia e imaginación". Teoría de lageografía.

Buenos Aires: G.A.E.A. Sociedad Argentina de Estudios Geográficos OIKUS. Asociación para la Promoción de los Estudios Territoriales y Ambientales, 1984, 210-225.

Vicent, Manuel, "Por la ruta de la memoria. La Habana". El País Semanal. Madrid: 10, Mayo, 1987: 55-59.

Wright, John K. "Percepción y descripción”. Teoría de la geografía. op. cit., 167182. 